This paper is the accepted, not published, version. Please do not cite without express permission from the authors.

\title{
Religious Literacy of Australia's Gen Z Teens: Diversity and Social Inclusion
}

Anna Halafoff ${ }^{\mathrm{a} *}$, Andrew Singleton ${ }^{\mathrm{a}}$, Gary Bouma ${ }^{\mathrm{b}}$ and Mary Lou Rasmussen ${ }^{\mathrm{c}}$

${ }^{a}$ Deakin University, Geelong, Australia; ${ }^{b}$ Monash University, Melbourne, Australia;

${ }^{c}$ Australian National University, Canberra, Australia

*Corresponding Author: Faculty of Arts and Education, Deakin University, Geelong Waurn

Ponds Campus, Melbourne, VIC 3216, Australia. Email: anna.halafoff@ deakin.edu.au

This work was supported by the Australian Research Council

ARC DISCOVERY PROJECT: DP160102367 


\title{
Religious Literacy of Australia's Gen Z Teens: Diversity and Social Inclusion
}

\begin{abstract}
Australia is a culturally, religiously and linguistically diverse country, however, learning about the religious dimensions of this superdiversity is inadequately reflected in the national school curriculum, notwithstanding recent attempts to address this at the state level in Victoria. Debates regarding the role of religion in school have raged across the country for decades and have impeded the introduction of learning about diverse worldviews and religions, and even research on this topic. Competing views of Australia's national identity, as a multifaith and/or secular and/or Christian nation continue to affect both policy and curriculum in Australia, and thereby the level of religious literacy of its citizens. Using data from a national study of young Australians and their worldviews, this research investigates levels of religious literacy and appreciation of religious diversity of 'Generation Z' Australians, for whom superdiversity is the norm. In doing so, it concludes that Australian curricula must evolve to include more content on diverse worldviews and better reflect the lived experiences of younger generations. This would in turn increase religious literacy and interreligious understanding in Australia. This study may also be instructive for those countries grappling to adjust to similar demographic and societal changes, challenges and opportunities.
\end{abstract}

Keywords: religious literacy; superdiversity; Generation Z; education; Australia

\section{Religious literacy, education and peacebuilding}

P1: It's good to learn about other people's like beliefs so that you can become a more accepting person because if you understand what they believe - like even if you don't believe it yourself, if you understand what they believe then you can like...

P2: [understand] their actions.

P1: Yeah...

P2: The more accepting you are. <Participants in AGZ study Focus Group 2017>

Religion and education have long been the subject of academic inquiry, becoming a notably 'hot topic' after the events of September 11, 2001 and the 2005 London bombings. Fears of homegrown terrorism led to an increased interest in the role education may play in preventing violent extremism and promoting more socially cohesive societies. This discussion occurred primarily in the United Kingdom, the European Union and other places in the global north, 
including the United States, and Canada. Catalysing this interest, Stephen Prothero published his ground-breaking book on Religious Literacy: What Every American Needs to Know - and Doesn't in 2007, and since then there has been an expanding argument about the need to increase religious literacy among young people worldwide as an effective response to the social consequences of religious diversity. In addition, the Harvard Religious Literacy Project (HRLP) was founded in 2011, continuing the legacy of the Program in Religious Studies and Education that began in the 1970s (HRLP n.d.d), and Adam Dinham and Matthew Francis released their edited collection on Religious Literacy in Policy and Practice in 2015 .

Most scholars agree that contemporary societies are much more religiously diverse than they once were and thus there is a need to better understand our neighbours and also the role religions are increasingly playing in world events (e.g. Prothero and Kerby 2015). Prothero and Lauren R. Kerby (2015) note that religious literacy 'can also lead to a more robust tolerance' (74) but that it has been complicated by 'culture wars' (65) around competing notions of national identity. This has certainly been the case in Australia, as will be explained in detail below. Moreover, Diane. L. Moore, Founding Director of the HRLP, and the American Academy of Religion (HRLP n.d.b) states that religious literacy comprises:

1) a basic understanding of the history, central texts (where applicable), beliefs, practices and contemporary manifestations of several of the world's religious traditions as they arose out of and continue to be shaped by particular social, historical and cultural contexts; and 2) the ability to discern and explore the religious dimensions of political, social and cultural expressions across time and place.

They add that it is crucial to understand religion and its influences 'in context and as inextricably woven into all dimensions of human experience' (HRLP n.d.b). The HRLP stresses that religions are 'internally diverse', that they 'evolve and change over time' and that 'religious influences are embedded in all dimensions of culture' refuting 'the assumption 
that religions function in discrete, isolated, "private" contexts' (HRLP n.d.c). The HRLP also stressed that religious illiteracy is widespread globally, and that it is of urgent concern in that it 'fuels conflict and antagonisms and hinders cooperative endeavors' (HRLP n.d.a). Furthermore, the HRLP is concerned with religions' influence in direct, structural, and cultural forms of violence and peacebuilding, including creating and countering gender and sexuality inequality (HRLP n.d.e).

For Francis and Dinham $(2015,266)$ religious literacy is 'having the knowledge and skills to recognise religious faith as a legitimate and important area for public attention', as well as acquiring a general knowledge about diverse religions and 'an awareness of and ability to find out about others'. They describe it as a civic rather than a religious endeavour, that 'seeks to support a strong multifaith society, that is inclusive of people from all faith traditions and none' (266). Its purpose, write Francis and Dinham 'is to avoid stereotypes, engage, respect and learn from others, and build good relations across difference'. Dinham (quoted in On Religion, 2016) also notes that religious literacy entails critical thinking and is aligned with liberal values, human rights and social justice. Francis and Dinham $(2015,270$, 261) further emphasise that religion is becoming more 'complex' and that there is a pressing 'need to understand the real religious landscape', which is 'context-sensitive'.

These frameworks of religious literacy, and arguments about the need for them, strongly align with recent scholarship on learning about worldviews and religions (LWR), notably Robert Jackson's (2014) Signposts: Policy and Practice for Teaching about Religions and Non-Religious Worldviews in Intercultural Education published by the Council of Europe (CoE). Indeed, LWR programs in schools are a critical component of developing religious literacy. Signposts states that this type of education is desirable in order 'to promote mutual understanding and democratic citizenship' (15) and aims to 'provide knowledge but also to cultivate sensitivity, reciprocity and empathy and to combat prejudice, intolerance, 
bigotry and racism' (16). Jackson $(2014,16)$ also 'acknowledges that such provision needs to be supported by high-quality teacher training, rich and varied resources, and ongoing research and evaluation'. In terms of religious literacy specifically, Jackson (2014, 54 quoting Knauth 2009), also highlights the need for students to develop a competence in analysing 'the role of religion in social life', and particularly 'media representations of religion'.

In summary, and drawing upon these frameworks, we argue that religious literacy responds to the critical need for students to have more knowledge about diverse religions, and the complex interactions between religion, culture, society and politics in increasingly religiously diverse societies, and at a time when religion plays a prominent role in the public sphere. Religious literacy should be part of a wider civic project that seeks to combat prejudice, and negative stereotypes of religious groups often perpetuated by media and political discourses, and to build mutual respect within multifaith societies. It is thus a peacebuilding endeavour, which aims to contribute to the creation of harmonious and inclusive superdiverse societies, where differences and conflicts can be examined critically and resolved without violence.

Religious literacy can be encouraged through learning about worldviews and religions (LWR) in schools, and such programs need to be context-specific. They should also stress the complexity, internal diversity and changeability within non-religious and religious worldviews, and reflect young people's every day, lived religious expressions and experiences. LWR can also contribute to countering false and negative stereotypes about religion and worldviews, and to identify where religion plays a role in conflict and violence, both structural and direct, and address this. LWR can also explore the peacebuilding aspects and potential of religions.

We therefore turn now to an examination of the Australian context, with regard to both religious composition and educational programs about diverse religions and 
worldviews, and also provide an analysis of new data on the worldviews and religious literacy of Australian 'Gen Z' (AGZ) teenagers (aged 13-18 at the time of our study, born between 1999 and 2004). We then conclude by critically examining this data and making a series of recommendations pertaining to improving the religious literacy of young Australians.

\section{The Context: Emerging Religious Diversity in Australia}

This section describes recent changes in Australia's religious profile. As will become apparent, young Australians have only ever known a society in which diversity is the norm. Australia has a richly diverse population of nearly 25 million. Indigenous peoples spoke over 250 languages and 600 dialects and continue to produce, and reproduce, richly diverse cultures with many societies, nations and religions (Bell 2009; Carey 1996, 2009). Since colonisation in the eighteenth century, Australia's changing religious profile has largely been a product of immigration (Jupp 2009a, 2009b). A wide diversity of convicts and immigrants, including Christians and Jews, and later Taoists, Confucians, Buddhists, Muslims, Hindus and Sikhs, settled in Australia and also worked in Australia's goldfields, cotton and sugar plantations, as pearl fishers or camel drivers before the introduction of the 1901 Immigration Restriction Act - popularly known as the White Australia Policy. Australia, as a predominantly white, Christian nation, was a social construction that lasted until the policy's final demise in the 1970s. Australia ranked 35 on Pew's 2010 Religious Diversity index, out of 232 countries (2014). It is one of the most religiously diverse nations in the world as a result of recent high levels of immigration and geographical proximity to Asia and the Pacific nations (Bouma 2016; Bouma and Halafoff 2017; Croucher 1989; Ganter 2008; Jupp 2009b; 2018). 
The religious composition of Australia has long been measured in data provided by the Australian Census, conducted every five years. The census reports in Table 1 demonstrate that religious diversity is an ever-increasing reality.

\section{PLACE TABLE 1 ABOUT HERE}

Table 1 shows the proportion of those identifying with mainline Christian groups, of Anglican, Methodist, Congregational, Presbyterian, Reformed and Uniting faiths, has declined dramatically from 1911 to 2016 . By contrast the proportion of those identifying with religions such as Islam, Hinduism, Buddhism, and Sikhism has increased significantly. There has also been a dramatic rise in the proportion of the population declaring that they have 'no religion', including substantial numbers of Chinese immigrants.

Those declaring that they have 'no religion' represented $30.1 \%$ of the population (7,040,700 people) in 2016, and is the single largest group. The two largest religious groups in Australia are Catholics (22.6\%) and Anglicans (13.3\%). Australia also now boasts three substantial religious minority communities - Muslims $(604,200)$, Buddhists $(563,700)$, and Hindus $(440,300)$ - each being around $2-2.5 \%$ of the population (ABS 2017a). This is globally distinctive as a result of Australia's geographical proximity to Asia, as for example, the UK and EU have far higher percentages of Muslims, than Buddhists and Hindus (Bouma 2016; Bouma and Halafoff 2017). British Protestant and Anglican groups continue to decline and age, the effect of greatly lessening the British ties and cultural influence. Having once completely dominated the society these groups are challenged to find a voice and place in the new superdiverse Australia. Some now feel under attack not just by the rise of religious diversity but also by the rise of religious 'nones' (Bouma and Halafoff 2017).

Importantly, religious change is not uniform across society. Table 2 uses census data to examine the different religious profile according to 'generations' in Australia. We have followed the Pew Research Centre's convention of identifying various age cohorts as 
'generations': Silent (to 1945) at $10.6 \%$ of the population in 2016; Boomers (1946-1965) at 23.4\%; Gen X (1966-1981) at 20.2\%; Millennials (1982-1996) at 21.1\% and Gen Z (19972016) at $24.7 \%$.

\section{PLACE TABLE 2 ABOUT HERE}

Anglicans, Presbyterians, Reformed, Uniting, Baptists, and Lutherans are disproportionately found in the older generations; this will result in the continued decline of these groups as a proportion of the population. By contrast, Catholics, Pentecostals, Muslims, Hindus, Sikhs and Buddhists have much more youthful profiles, due in part to many being recent migrants to Australia.

For the Silent and Boomer generations, who were raised in the early to mid-twentieth century, the socially constructed myth of a majority white Christian Australia was, and for many remains, their reality. These generations also followed and continue to follow an 'old style religion' model, in which they typically belonged to a single religious affiliation, regularly attended a local religious organisation and basically followed the same rules (Woodhead 2012). Christianity remains the dominant religious group in both of these generations, however they too are diverse with significant proportions of nones, and including smaller numbers of Jews, Buddhists, Muslims and Hindus.

As stated above, the 1970s heralded a time of global flows of immigrants, and also religious seekers and teachers, in and out of Australia. It was also an era of new religious movements (NRMs) and the beginning of 'new style religion' and spirituality that is characterised by diversity, fluidity, individual choice, and hybridity (Woodhead 2012). The spiritual-seeking Boomers were pioneers of the new style, although many remained entrenched in the old style, while some began to turn away from religion altogether (Clarke 2006). 
For Generation X, raised in the 1960-80s and for the Millennials raised in the 1980smid-90s, exposure to these changes meant that cultural diversity was normalised, and multiculturalism widely appreciated. These generations, with Silent and Boomer parents, also grew up with both old and new styles of religion and spirituality present around them and influencing their own lives, however religion did not feature so prominently in the public mind, as it did for Generation Z, raised in the mid-90s onwards, in a post-9/11 and postsecular period, that we argue was rather brief. Gen Xs and Millennials are now far less religious than their parents, less Christian and more religiously diverse as well. Millennials, according to the Census data are the least religious Australian generation.

Gen Zs have Gen X parents, many of whom turned away from old-style religion and embraced new forms of spirituality, and/or practices associated with spirituality such as yoga, meditation and astrology. They also are growing up in a time where there is increased critique of old style conservative and extremist religion, and of the post-secular closer ties between religion and state, which occurred at the turn of the twentieth century. They have been raised within global communication systems and saturated by social media, at a time when religious authority has been highly scrutinised as a result of these technological advances, and particularly increased openness and transparency. Gen Zs, according to the Census data, include fewer nones and more Christians than the Millennials, but this is possibly as a result of parents filling out their census forms, and also of particularly Catholic and Pentecostal immigration, and Pentecostalism's tailoring of its service to appeal to young people. There are also more Gen Z Muslims, Sikhs and Jews and fewer Buddhists and Hindus, than in the previous generations.

However, Census data on religion, by giving participants a chance to only pick one option, does not tell us too much about young people's actual lived experiences or 
perceptions of this diversity, nor does it tell us anything about their levels of religious literacy. This is what we set out to investigate in the AGZ study.

We found that religion, spirituality, and critiques of religion and spirituality are part of Gen Zs everyday lives, with 'everything going on at once' (Woodhead 2012). This superdiversity is increasing; young people seem to be understanding and respecting it, not only in terms of culture and religion, but also gender, sexuality and multispecies diversity. Yet, most Australian Gen Zs in government schools are not receiving any education about religious diversity, and the types of education programs that are currently being delivered do not adequately match their lived experiences and appreciation of superdiversity. This is in large part due to long-ranging debates regarding the role of religion in secular education in Australia, although recent developments in Victoria demonstrate that this context is evolving in response to recommendations from scholars, and religious and non-religious community leaders and activists.

\section{Learning about worldviews and religions in Australia}

Australia currently has three education sectors. In 2017, out of 3,849,225 students enrolled in 9,444 schools, $65.6 \%$ of students attended government schools, $19.9 \%$ Catholic schools and 14.5\% private independent schools (ABS 2017b). Australia's government schools were established in the mid-late 1800s and initially included some teaching of Christianity, however, by the 1870 s most of the colonies' education systems prohibited the teaching of religion in school hours to avoid sectarian divisions (Byrne 2014; Maddox 2014). By the early twentieth century education acts in NSW and Tasmania enshrined 'free, compulsory and secular' education in these states but still permitted religious representatives to provide confessional religious instruction (RI, also known now in some states as SRI, Special religious Instruction or RE, Religious Education) to students (Maddox 2014, 54). By the 1950s, all Australian states had some form of RI/SRI/RE in government schools delivered by 
religious volunteers, from Christian and/or Jewish traditions, and at the turn of the twentyfirst century, RI/SRI/RE was also offered in government schools by so-called minority religions including by Buddhists, Hindus, Muslims, Baha'is, Sikhs and Orthodox Christians (Halafoff 2015; Maddox 2014).

There is no dedicated General Religion Education (GRE) in the national Australian Curriculum from Foundation (Kindergarten) to Year 10. GRE, including education about diverse major religions, is being offered in a limited capacity in government schools in some states including NSW, Queensland and WA. Victoria, is the only state that includes dedicated content on Learning about world views and religions (LWR), which was recently introduced and replaced SRI in 2015 (Byrne 2014; Halafoff 2016; Maddox 2014). A detailed historical account of these changes is beyond the scope of this paper and has been published elsewhere (see Byrne 2014; Halafoff 2015; Maddox 2014) but what is important to note is that Australia's government secular schools until recently have provided very little opportunity for GRE, except for in the final two years of schooling in Years 11 and 12, as elective Religious Studies subjects, that are offered mainly in religious schools.

By contrast, Australia's Catholic schools provide Catholic Religious Instruction/Education and many also provide GRE from Foundation to Year 12 or at least in secondary schools. The third, private independent school sector is mixed, with many of these schools being faith-based schools and therefore providing RI/SRI/RE in their denomination and in some cases also GRE at junior and/or senior levels, while non-faith-based schools provide either no RI/SRI/RE or GRE or some GRE.

In Australia, similarly to other Western societies, scholars, policy makers and curriculum developers began to argue that GRE could play an important role in peacebuilding, by advancing social inclusion and in preventing violent extremism, in the mid-2000s. In particular we argued that GRE could play a significant role in countering 
negative prejudices and misinformation about religious groups perpetuated by the media and political figures. We flagged that this negative stereotyping was dangerous at it could play a part in processes of social exclusion and thereby vulnerability to radicalisation, both of young people from minority faith traditions who were being vilified as a result of this rhetoric, and also from within host communities with anti-migrant views who were persecuting minorities (Bouma et al. 2007). Calls for the expansion of GRE were, and continue to be, hindered by a contrasting agenda, as part of a narrow nation building project, to perpetuate the myth of Australia as a white Christian nation, focusing instead on the development of Judeo-Christian values (Halafoff 2015).

Scholarly consultation with the Australian Curriculum, Assessment and Reporting Authority (ACARA) led to some GRE content being incorporated within the recently introduced national Australian Curriculum learning areas of History and Civics and Citizenship and in general capabilities of Intercultural Understanding and Ethical Behaviour (Halafoff 2015). However, the 2014 Review of the Australian Curriculum ignored multiple calls for more content on GRE and instead recommended that ACARA 'better recognise the contribution of Western civilisation' and 'our Judeo-Christian heritage' (Donnelly \& Wiltshire 2014, 246). As Prothero and Kerby (2015) argue about the US, Australia's version of the 'culture wars' continues to influence curricula and policy, and this differs in every state. For example, and as briefly mentioned above, the more socially progressive state of Victoria's version of the national Curriculum, rolled out in 2016, included new dedicated sections on Learning about world views and religions (LWR) in the Humanities and also in Ethical Capabilities. This comprises content outlining the importance of LWR programs, citing Jackson's Signposts, and also the main tenets of Australia's major faith traditions of Buddhism, Christianity, Hinduism, Islam, Judaism and Secular humanism and rationalism (VCAA 2015a, 2015b, 2015c). This LWR content was prepared in consultation with 
Victoria's faith communities and scholars of religion, including two authors of this paper Bouma and Halafoff, and demonstrates that there has been significant progress to address the issue of religious literacy in Australia in recent years, at least in Victoria. ${ }^{1}$ Following these developments, the AGZ study, initiated in 2016, is the first to investigate levels of religious literacy among young Australians. The findings of the AGZ study could therefore inform national and state curriculum development in these areas, by illustrating young people's contemporary understandings and lived experiences of diverse worldviews.

\section{The Australian Gen $\mathrm{Z}$ study on negotiating religion and diversity}

The data in this paper were collected as part of the 'Young Australians' Perspectives on Religions and Non-Religious Worldviews' project, referred also as the Worldviews of Australian Gen Z (AGZ) study, an Australian Research Council funded national study that explores teenagers' experiences and understandings of religious, spiritual, gender and sexual diversity. The Chief Investigators of this project are Professor Mary Lou Rasmussen (the Australian National University), Professor Andrew Singleton and Associate Professor Anna Halafoff (Deakin University) and Professor Gary Bouma (Monash University). The AGZ study, conducted in 2016-2018, comprised: 11 focus groups with a total of 94 students in Years 9 and 10 in three states (ages 15-16); a nationally representative random-digit-dial (RDD) telephone survey of 1200 people aged 13-18; and 30 in-depth, follow-up interviews with survey participants. In this paper, we report on the focus groups and survey only. (To improve the representativeness of the survey, data are weighted by age, gender, location and telephone status. In probabilistic terms, the maximum margin of error to apply to this survey is $\pm 2.8 \%$.) The AGZ study's aim is to enhance and inform debates about how education

\footnotetext{
${ }^{1}$ LWR in Victoria's schools was first implemented in 2016. Halafoff, Bouma and Jackson, are currently undertaking an analysis of this program, including its content, pedagogy and reception in schools, as part of another Australian Research Council (ARC DP180101664) project on 'Religious Diversity in Australia,' led by Douglas Ezzy. It is too early to report on any findings in this paper.
} 
assists or impedes religious literacy and intercultural understanding as well as enhancing wellbeing and social inclusion. Knowing more about young people's perspectives and what influences them can facilitate development of appropriate educational responses in schools, and, at the level of educational policy development.

\section{Religious literacy of Australian Gen Z Teens}

Using data from the AGZ study we explore the religious and spiritual identification of Australian teens and their levels of religious literacy, including their knowledge about and also attitudes towards diverse worldviews and religions. Additionally, we explore what kinds of education, if any, they have received about diverse religions and worldviews, and if it has made any difference to students' attitudes to religions and religious diversity.

\section{Religious Identification of Gen Z Teens}

In the AGZ survey 13-18-year-olds answered the question of religious affiliation themselves. As shown in Table 3, In the AGZ survey 52\% of respondents said they were nones. The largest group of Christians are Catholic (19\% of those aged 13-18), while Buddhists, Hindu, Muslim teens represent approximately six per cent of the population.

\section{PLACE TABLE 3 ABOUT HERE}

We also asked survey participants about whether they identified with more than one religion. Eight per cent of those who said they had one religion also said they had another. There is no particular pattern of identification: respondents with a 'hybrid' identity come from across the spectrum of religions.

We also asked survey participants about their self-identification in terms of religion and spirituality: $35 \%$ said they were neither religious or spiritual; $22 \%$ said they were 'spiritual but not religious'; 16\% declared they were 'religious and spiritual'; $12 \%$ were 'religious but not spiritual'; and 14\% could not choose from those categories. In terms of 
alternative practices and beliefs, $20 \%$ believed in astrology, $30 \%$ in reincarnation, $50 \%$ in karma; $22 \%$ had practised yoga and $30 \%$ had practised meditation. Both yoga and meditation are routinely incorporated into wellbeing and resilience programs at secondary schools. The somewhat higher level of belief in karma is an interesting development. It is likely that teenagers refer to it in a casual way in everyday life, yet it does indicate some latent level of openness to spiritual possibilities and religions of Asia.

\section{Religious Literacy Exercise}

In addition to investigating religious and spiritual affiliations and practices in the AGZ survey, the focus groups set out to specifically investigate levels of religious literacy among Gen $\mathrm{Z}$ teens. They began with an exercise in which students were asked to identify a number of images associated with diverse religious traditions. Indigenous, Catholic, Buddhist and Yoga images of Uluru, Pope Francis, the Australian saint Mary McKillop, the Dalai Lama. In this exercise the Yoga pose, and Buddhist statue had the highest level of recognition. Some students identified images of an Anglican church, the Pentecostal church Hillsong, the Wailing Wall, a mosque, a Muslim public intellectual Yassmin Abdel-Magied, and Richard Dawkins, while no students recognised the image of a labyrinth, Muslim politician Anne Aly, or an atheist symbol.

Overall Australian Gen Z teens demonstrated a moderate level of religious literacy in this limited exercise by recognising in broad terms most of the images shown to them. At the same time, students often guessed images incorrectly, and it is interesting to note how even when students mistook an image they had a wide and varied religious and spiritual repertoire and vocabulary to draw upon. For example, while none of the students knew what the labyrinth image was, some remarked it was 'a maze', quite a few thought it was an Indigenous Australian art work while some had other ideas including something made by 'Egyptians, an ancient perhaps tradition or something?', 'a ritual site', 'Nazca Lines' from 
Peru, a 'Native American tribe' symbol, 'crop circles” and 'alien patches'. Yet while they displayed a breadth of knowledge, very few student's level of religious literacy was particularly deep. To illustrate, many Christian and non-religious students identified the Dalai Lama image correctly but also many did not. When pressed a little further on what the students knew about him, some seemed to know very little. One student remarked he was 'famous' but did not know why. Another student asked 'is he an authority figure, because I don't know', while others further questioned:

Q1: So does anyone know who the Dalai Lama is? ...

P1: Well, we kind of, we don't know very much about it.

P3: I've heard of it before.

P2: I don't know what the Dalai Lama does, is he like the Pope of his religion?

Q2: I think that's a good way of describing it, yeah.

Q1: He is. I reckon that's a good call. Yeah. Of Buddhism.

Those that did recognise him also described him as 'Buddhist', 'a Buddha', 'a monk' and as a 'leader' and 'representative' and the 'Pope for Buddhism'. One non-Buddhist student from a selective private school gave an enthusiastic and relatively well-informed response:

He's really adorable. He's the spiritual leader of the Tibetan people. Ah, I believe - I'm pretty sure it's Buddhism. He's the leader of the Buddhist movement. Um, he's the 15th Dalai Lama I think. This is just from, ah, I read somewhere. Ah, that's about all I know.

He is actually the $14^{\text {th }}$ Dalai Lama, she was very close. One student mistook him for a 'Hindu monk' and another student from a secular government school equated the Dalai Lama with a non-materialistic view and with 'spiritual things'.

Christian students, not surprisingly, had a higher level of literacy when it came to Christian images, and minority faith students recognised minority faith images with greater ease. Students from some Christian, minority-faith and government selective schools ${ }^{2}$ demonstrated a deeper level of religious literacy, as noted above, while some faith-based

\footnotetext{
${ }^{2}$ Selective schooling and partially selective schooling is common across Australian public schools. Students must satisfy particular requirements in academic, arts or sporting endeavours to gain entry to these schools.
} 
school students, of Christian and minority faiths, displayed a lower level of religious literacy by comparison. Students in non-selective government schools' levels of literacy were generally moderate. ${ }^{3}$ In short, access to elite education, not surprisingly, had a positive relationship to levels of religious literacy.

\section{Education about Religion among Gen Z Teens}

In this section we explore what the survey data reveals about the ways in which students learn about religion at school. This is shown in Table 4.

\section{PLACE TABLE 4 ABOUT HERE}

Table 4 shows the kinds of education about religion Australian teens have received at secondary school. Consistent with the policy approaches outlined in the previous section, the survey asked about the two different kinds of education about religion that Australian secondary school students are likely to encounter: General Religious Education (GRE), which we defined as: 'General education about religions, that is, lessons or information about the major religions of the world, like Islam, Christianity, Buddhism or Aboriginal religions'. This is distinct from Specific Religious Instruction (SRI), which we defined as: 'Specific religious education, that is, lessons on the beliefs and practices of [a particular faith]'. Depending on the kind of school the respondent attended, these questions were modified to be appropriate for that schooling context. Both SRI and GRE are abiding ways of fostering religious literacy.

Looking at the column on the right, the survey data show that approximately $27 \%$ of Australian secondary school students have received both GRE and SRI. Approximately the same proportion (28\%) have received GRE only. Taken together, this means that at least half

\footnotetext{
${ }^{3}$ Students in non-selective state schools are also likely to experience disadvantage related to socio-economic status, relative to students in Independent, Christian and state selective schools. This means that they are likely to continue demonstrate lower levels of literacy relative to peers in other schools, regardless of curriculum (Windle 2016).
} 
(55\%) of Australian secondary school students have had some form of GRE. By contrast, $41 \%$ have had no education on religion at all, a substantial proportion, and only $4 \%$ claimed to have had only SRI.

As the Table illustrates, and as noted above, the kind of school a person attends critically influences the kind of education they receive. Consequently, we see that $56 \%$ of students attending schools in the government sector have received no education about religion, while $42 \%$ of those attending independent private schools have received no education about religion. Only $2 \%$ of Catholic students claimed to have had no SRI or GRE. This is possible if the student arrives in a school in the senior years, when SRI and GRE may not be part of the senior curriculum. By contrast, SRI is routinely offered in Catholic schools. For the most part, our data show that Catholic schools teach SRI in conjunction with GRE: $81 \%$ of Catholic students claim to have been taught both, compared to $37 \%$ of students in the independent private system.

In our survey, we also sought to discover the extent to which students valued GRE and its importance in fostering religious literacy, tolerance and understanding. Students overwhelmingly endorse the benefits of the GRE they have received: 93\% agree or strongly agree that it was helpful in developing an understanding of other people's religions; $86 \%$ agreed or strongly agreed that GRE helped make them more tolerant of other people's religions; $82 \%$ agreed or strongly agreed with the proposition that GRE was something important to study. There are no important or notable differences between students attending different kinds of schools; all are generally likely to have these positive views. Thus, for the most part, students who have had this kind of education overwhelmingly endorse its broader social value and importance. Of those who had not had GRE at school, the large majority $(69 \%)$ were interested in lessons about the world's religions; the majority of these students 
$(67 \%)$ were also interested to have lessons on non-religious perspectives and values, including ethics, humanism and rationalism.

Outside of school, there are other notable ways in which young people are developing their religious literacy. Table 5 examines other sources of information. Survey participants were asked, 'From the time when you started secondary school, have any of the following been helpful sources of information about the world's religions?' and offered with a range of responses.

\section{PLACE TABLE 5 ABOUT HERE}

These results show that Australian teenagers are interested in sourcing information on religion from a range of places. School, family, media and the peer interactions that occur at school, figure prominently as additional sources of religious literacy. This includes discussions with those who follow a particular faith at school (78\%) and on the internet (69\%). Direct religious experience, such as attending a service, is the least common source of religious information $(47 \%)$.

\section{General Religious Education and attitudes to religious diversity}

It is valuable to consider the relationship between the types of education about religion young people have received and broader attitudes to religion in society, a crucial component of religious literacy. As part of the study, we asked about attitudes to different aspects of religious diversity. For the most part, young Australians affirm and are open to religious diversity in Australia and think different faiths should have religious freedom. By way of illustration, $91 \%$ of teenagers think that having people of many different faiths makes Australia a better place to live; $90 \%$ think that students should be allowed to wear religious clothes or jewellery to school; and $88 \%$ think that all religious groups in Australia should be free to practise their religion the way they want to. 
However, opinion is divided when it seems that religion might impinge on them: $44 \%$ think that religion causes more problems in society than it solves; $50 \%$ think people with very strong religious beliefs are often too intolerant of others; $33 \%$ think religion should have no place in our parliament or official ceremonies; $32 \%$ think that local communities should be able to prevent the construction of mosques or temples in their area if they do not want them. We found this last result particularly concerning; it was also somewhat incongruent with young people's general embrace of diverse faiths. The AGZ Survey also finds that about a third of those who identified with a religion apart from Christianity had experienced some kind of discrimination of the basis of their religion. This suggests that there is further work to be done in fostering religious understanding.

We found those young people who have had both GRE and SRI tend to exhibit stronger positive attitudes to religion than those who have had no general religious education. In other words, there was a statistically significant relationships between the kinds of education students have received and their attitudes to religion's place in society. For example, $20 \%$ of those who have had GRE/SRI think that the government should ban any religious clothing that covers a person's entire face compared with $27 \%$ of those who have had no education about religion. There are more notable differences, however, when it comes to attitudes to Australia's religious minorities. These are evident in Table 6.

\section{PLACE TABLE 6 ABOUT HERE}

Those who have received both GRE and SRI have the most positive view of all the diverse religious groups, while those receiving no GRE or SRI have the least positive views of all diverse religious groups and of nones. Those who have had GRE only, have the highest positive attitude to nones and also highly positive attitudes to religious minorities, but less positive views of Christians than those with SRI and GRE. Although too small in number to form really reliable conclusions, some statistically significant patterns do seem to be evident 
in the 'SRI only' group. This group has the least positive view of Muslims in particular and the most positive view of Christians. Many in this group attend evangelical Christian schools.

Students who have received GRE have the most positive views of the diverse religious groups in Australia. By contrast, students who have had no GRE are about twice as likely as those who have had GRE (whether on its own or with SRI) to hold negative or neutral views towards Australia's religious minorities, even when controlling for factors such as age, gender, school type, socio-economic status and religious identity. These findings suggest that GRE may have some utility in improving a teen's views about other groups, while having SRI only may not assist in improving a teen's views of about other faiths, rather, it may entrench existing attitudes. Notably, our data suggest that GRE programs are associated with reduced negative perceptions of religious minorities.

This was well-illustrated in focus group discussions in both religious and nongovernment schools. A student from a Christian school explained how, ... we were studying religions and ... we did go and visit like a Hindu temple [nearby].. There were people there that were representatives, they were talking about it and stuff like that... But, um, in just normal classes, most of the time the teacher will call on educational like a documentary... it feels like the whole purpose of it is to teach people who aren't of that religion who said it was being like this ... for people who are like, with the Islamic faith that we just kind of finished doing, it was a documentary. And, um, it was people or teenagers who were so like a female and male, talking about the different perspectives and... A few kids were a bit, like, they kind of might have taken it - especially my class, kind of, did take it a bit as a joke at first... especially involved with what is happening in the world... you know, with the whole thing, Muslims are terrorists and stuff like that. [But i]t was a bit like awesome, okay, we're now learning about the Islamic faith and kids were like, hang on, wait a second...

And at a selective government school, students explained how they learned about diverse religions and non-religious worldviews including Humanism and Marxism and Feminism, in Humanities and in Ethics classes, linked to topics such as human rights, the United Nations and world peace. Students at this school were encouraged to undertake personal research projects, which at times focused on religion. One of the students recently 
presented on reincarnation, while another spoke of her experiences of discrimination as a young Muslim woman in Australia. Students expressed empathy toward her and also stated that what they had learnt in school helped them to counter negative and misguided generalisations about Islam and Muslims.

P2: Yeah, so I did this speech, like three minutes to change the world... you could speak about whatever you want. So then... This girl did a speech... and she spoke about how she's discriminated against.

Q1: On the basis of her...

P2: Religion.

P3: Religion.

Q1: And she was?

P2: Muslim.

P1: But that was less about being like discriminated at school and more about just the fact that

P2: Society.

$\mathrm{P} 1$ : ... about terrorism right now and because she's Muslim people of some reason...

P2: Make ignorant comments.

P1: ... relate Muslim[s] to terrorism. So things about like the typical Australian ... 'Get out of my country.' But to an extent I feel like that's more of a thing of the past. Like as we're coming into this new generation because there's so much on the news that we are slightly scared of this idea of terrorism. But I think with the things we're learning at school we're starting to $[\mathrm{be}] \ldots$.

P2: More accepting.

P1: ... [and] more open minded to how [Islam] might not be related to terrorism specifically. P2: Yeah.

It is also of interest to see how different school sectors may impact on views of different religious and non-religious groups. This is represented in the final Table.

\section{PLACE TABLE 7 ABOUT HERE}

Table 7 shows that those who attend Catholic schools have a more positive view of different faiths, particularly Muslims and Christians. As noted earlier, Catholic students are the group most likely to have had GRE of some kind. Those in government schools had more positive views of those with no religion and also a high opinion of Buddhists and Christians. Overall the group that is viewed most positively are Christians, a finding that maybe of interest for those who fear that Christianity is under attack in Australia. It is also important to note here that numbers of both Hindus and Muslims in Australia are increasing, and that both 
groups have experienced discrimination and vilification in recent years (Markus 2017). This Table demonstrates that around $25 \%$ of Gen $\mathrm{Z}$ teens hold less than positive views about these groups, with up to $30 \%$ of students from government and private schools holding less than positive views about Muslims. As noted above the private sector contains both religious and non-religious schools.

\section{Conclusions}

Our findings from a study of Gen $\mathrm{Z}$ teens, alongside other international research, suggest that introducing dedicated GRE programs or wider learning about worldviews and religions (LWR) in the Australian Curriculum and in all types of schools across Australia will not only increase religious literacy but also decrease negative stereotypes, prejudices and discrimination against religious minorities. This in turn will strengthen a sense of belonging, social inclusion and harmony among young Australians, and play a significant role in preventing violent extremism (PVE) and peacebuilding more broadly. ${ }^{4}$

In terms of how LWR should be implemented and designed, we agree that context needs to be a central component of religious literacy and that in Australia, it means being aware of our historical and contemporary cultural, spiritual and religious composition and the fact that education is the responsibility of both national and state governments. With regards to content, Indigenous Australian's history of and perspectives on spiritual and religious diversity should form a significant part of LWR curriculum in Australia. Mindful of Australia's history of immigration, LWR programs should also focus on Christianity and Judaism, and also on faiths such as Buddhism, Islam, Sikhism, and Hinduism, that have made significant contributions to and maintain a strong presence in Australian society. Moreover, it

\footnotetext{
${ }^{4}$ For a more detailed account of education and PVE in Australia see: Halafoff, Anna, Kim Lam, and Gary Bouma. 2019. "Worldviews Education: Cosmopolitan Peacebuilding and Preventing Violent Extremism," Journal of Beliefs and Values. 40(3): 381-395.
} 
is vital that LWR include teaching about non-religious traditions and beliefs, that have also long been present in this country.

We also argue that the way we conceptualise religious diversity and therefore religious literacy needs to better match the complex lived experiences of Gen Z Australians. This means not only exploring religious and non-religious worldviews, but a variety of spiritual practices, such as yoga and meditation, that are being widely adapted to secular contexts. The AGZ study demonstrated a wide breadth of religious and spiritual literacy but also students' level of understanding about worldviews and religions was not particularly deep. More LWR content across the curricula, including in the learning/subject area of History and in the general capabilities of Ethical Understanding and Intercultural Understanding, or even a new dedicated LWR learning area or general capability ${ }^{5}$ would begin to address this critical issue in a more meaningful fashion. This needs to also be supported by LWR teacher training programs. In 2018 the Victorian Curriculum and Assessment Authority sought to address what they perceived as teachers' reluctance to address this learning area through professional development. Lingard and McGregor (2014, 104) note: "It is at this point of 'translation' that many teachers may get lost, particularly if, as is too often the case, they are not trained to teach particular subjects and have limited pedagogical content knowledge" which is likely the case in respect to LWR.

Beyond issues of teacher professional development to curriculum content, LWR might also be enhanced by a greater emphasis on religious hybridity, and complexity. Given current national debates about religious freedom and religious exemptions, it might also include discussion and debate not only on respecting religious freedom but also the way in which religious freedom can impinge upon the rights of others. The AGZ study demonstrates

\footnotetext{
${ }^{5}$ The Australian Curriculum contains both learning/subject areas and general capabilities across them: "Threaded across each subject area are the 'general capabilities', identified as being essential skills for 'students to live and work successfully in the twenty-first century" (Lingard and McGregor, 2014, 103)
} 
that Gen Z Australians, when they are made aware of these issues, are highly resistant to religious privileges that may impinge upon other's freedoms.

We recognise that this is quite a long wish list and that internationally, there are steep challenges in implementing critical and quality education about worldviews (Gardner et al, 2017). However, the AGZ study suggests that given the high proportion of religious discrimination reported by Gen $\mathrm{Z}$ teens, despite their widely held positive views of diversity, there is an urgency to address Australian's shallow level of religious literacy. We argue that Australian curricula must evolve to better reflect the 'real religious landscape' and especially the lived experiences of superdiverse Gen $\mathrm{Z}$ teens, and include more LWR content to increase religious literacy and interreligious understanding in Australia.

\section{References}

ABS (Australian Bureau of Statistics) 2017a. Religion in Australia. Canberra: ABS http://www.abs.gov.au/ausstats/abs@.nsf/Lookup/by\%20Subject/2071.0 2016 Main \%20Features Religion\%20Data\%20Summary 70

ABS (Australian Bureau of Statistics) 2017b. Schools, Australia, 2017. Canberra: ABS http://www.abs.gov.au/ausstats/abs@.nsf/mf/4221.0

Bell, Diane. 2009. "Aboriginal and Torres Strait Islander Religions." In The Encyclopedia of Religion in Australia, edited by James Jupp, 69-96. Cambridge University Press, Melbourne.

Bouma, Gary. 2016. "The Role of Demographic and Socio-cultural Factors in Australia's Successful Multicultural Society: How Australia is not Europe.” The Journal of Sociology 52: 750-771.

Bouma, Gary, and Anna Halafoff. 2017. “Australia's Changing Religious Profile - Rising Nones and Pentecostals, Declining British Protestants in Superdiversity: Views from the 2016 Census," Journal for the Academic Study of Religion 30 (2): 129-143.

Bouma, Gary, Sharon Pickering, Hass Dellal, and Anna Halafoff. 2007. Managing the Impact of Global Crisis Events on Community Relations in Multicultural Australia, Multicultural Affairs Queensland and the Victorian Office of Multicultural Affairs. 
Byrne, Catherine. 2014. Religion in Secular Education: What in Heaven's Name are we Teaching our Children? Brill, Leiden.

Carey, Hilary. 1996. Believing in Australia: A Cultural History of Religions. Allen \& Unwin, Sydney.

Carey, Hilary. 2009. “An Historical Outline of Religion in Australia.” In The Encyclopedia of Religion in Australia, edited by James Jupp, 5-21. Cambridge University Press, Melbourne.

Clarke, Peter. 2006. New Religions in Global Perspective. London: Routledge.

Croucher, Paul. 1989. Buddhism in Australia, 1848-1988. New South Wales University Press, Kensington.

Dinham, Adam and Matthew Francis. eds. 2015. Religious Literacy in Policy and Practice. Bristol, Policy Press.

Donnelly, Keven and Kenneth Wiltshire. 2014. Review of the Australian Curriculum - Final Report, Australian Government Department of Education, Canberra.

Francis, Matthew and Adam Dinham. 2015. "Religious Literacies: The Future.” In Religious Literacy in Policy and Practice, edited by Adam Dinham and Matthew Francis, 257270. Bristol, Policy Press.

Ganter, Regina. 2008. "Muslim Australians: Deep Histories of Contact.” Journal of Australian Studies 32: 481-92.

Gardner, Ryan S., Kate Soules \& John Valk (2017) The Urgent Need for Teacher Preparation in Religious and Secular Worldview Education, Religious Education, 112:3:242-254.

Halafoff, Anna. 2015. "Special Religious Instruction and Worldviews Education in Victoria's Schools: Social Inclusion, Citizenship and Countering Extremism,” Journal of Intercultural Studies. 36(3): 362-379.

Halafoff, Anna. 2016. “Global Perspectives. Australia: Victoria.” In Religion and Nationhood. Insider and outsider perspectives on Religion Education in England, edited by Brian Gates, 369-378. Tübingen: Mohr Siebeck.

HRLP (Harvard Religious Literacy Project). n.d.a. “About.” Harvard Religious Literacy Project. Accessed May 27 2018. https://rlp.hds.harvard.edu/about

HRLP (Harvard Religious Literacy Project). n.d.b. "Definition of Religious Literacy." Harvard Religious Literacy Project. https://rlp.hds.harvard.edu/definition-religiousliteracy

HRLP (Harvard Religious Literacy Project). n.d.c. “Differentiations.” Harvard Religious Literacy Project. Accessed May 27 2018. https://rlp.hds.harvard.edu/differentiations 
HRLP (Harvard Religious Literacy Project). n.d.d. "History.” Harvard Religious Literacy Project. Accessed May 27 2018. https://rlp.hds.harvard.edu/history

HRLP (Harvard Religious Literacy Project). n.d.e. "Typologies of Violence and Peace." Harvard Religious Literacy Project. Accessed May 272018. https://rlp.hds.harvard.edu/typologies-violence-and-peace

Jackson, Robert. 2014 'Signposts': Policy and Practice for Teaching about Religions and Non-Religious Worldviews in Intercultural Education. Council of Europe Publishing, Strasbourg.

Jupp, James. 2009a. "Religion, Immigration and Refugees.” In The Encyclopedia of Religion in Australia, edited by James Jupp, 645-54. Cambridge University Press, Melbourne. Jupp, James. 2009b. "Ethnic Variety and Origins.” In The Encyclopedia of Religion in Australia, edited by James Jupp, 53-68. Cambridge University Press, Melbourne. Jupp, James. 2018. An Immigrant Nation Seeks Social Cohesion: Australia from 1788. London: Anthem Press.

Lingard, Bob, \& Glenda McGregor. 2014. "Two contrasting Australian curriculum responses to globalisation: What students should learn or become," Curriculum Journal, 25(1): 90-110.

Maddox, Marion. 2014. Taking God To School. Allen \& Unwin, Sydney.

Markus, Andrew. 2017. Mapping Social Cohesion: The Scanlon Foundation Surveys 2017. Monash University, ACJC, Melbourne.

On Religion. 2016. What is Religious Literacy? - Q\&A with Adam Dinham. 6 December 2016. http://www.onreligion.co.uk/what-is-religious-literacy-qa-with-adam-dinham/

Pew Research Centre:Religion and Public Life. 2014. Religious Diversity Index Scores by Country. 4 April 2014. https://www.pewforum.org/2014/04/04/religious-diversityindex-scores-by-country/

Prothero, Stephen. 2007. Religious Literacy: What Every American Needs to Know - and Doesn't. New York: HarperOne.

Prothero, Stephen and Lauren R. Kerby. 2015. "The Irony of Religious Literacy in the USA." In Religious Literacy in Policy and Practice, edited by Adam Dinham and Matthew Francis, 55-76. Bristol: Policy Press.

VCAA (Victorian Curriculum and Assessment Authority). 2015. "About the Humanities." Victorian Curriculum and Assessment Authority. Accessed May 202018. www.victoriancurriculum.vcaa.vic.edu.au/the-humanities/introduction/about-thehumanities 
VCAA (Victorian Curriculum and Assessment Authority). 2015. "Learning about World Views and Religions." Victorian Curriculum and Assessment Authority. Accessed May 20 2018. www.victoriancurriculum.vcaa.vic.edu.au/static/docs/Learning about World Views and Religions.pdf

VCAA (Victorian Curriculum and Assessment Authority). 2015. "Learning in Ethical Capability." Victorian Curriculum and Assessment Authority. Accessed May 20 2018. www.victoriancurriculum.vcaa.vic.edu.au/ethicalcapability/introduction/learning-in-ethical-capability

Windle, J. A. (2016). Making Sense of School Choice: Politics, Policies, and Practice under Conditions of Cultural Diversity. Dordrecht, Springer.

Woodhead, Linda. 2012. "New Forms of Public Religion: Findings and Reflections from the AHRC/ESRC Religion and Society Programme". Keynote address presented at the New Forms of Public Religion Conference, St. John's College, Cambridge, September 5-7. 